\title{
HUBUNGAN TINGKAT PENDIDIKAN DAN PENGETAHUAN IBU DENGAN PEMBERIAN ASI EKSKLUSIF PADA BAYI USIA 0-6 BULAN DI DESA MERANTI KABUPATEN MERANGIN JAMBI
}

\author{
Elisa Murti Puspitaningrum \\ Email : elisa_mpn@ymail.com \\ DIII Akademi Kebidanan Jakarta Mitra Sejahtera \\ Jl. Fatah Laside No 68, Kebun Handil, Kota Jambi \\ Telp/Fax (0741)40251
}

\begin{abstract}
Abstrak
Air Susu Ibu (ASI) merupakan sumber gizi yang sangat ideal bagi bayi. Namun kenyataannya, pengetahuan masyarakat tentang ASI masih kurang sehingga masih banyak ibu yang memberikan makanan selain ASI kepada bayinya. Penelitian ini bertujuan untuk mengetahui hubungan tingkat pendidikan dan pengetahuan ibu dengan pemberian ASI Eksklusif pada bayi usia 0-6 bulan di Desa Meranti, Kabupaten Merangin, Jambi. Penelitian ini bersifat deskriptif korelatif dengan desain cross sectional. Sampel dalam penelitian ini adalah ibu yang memiliki bayi usia 0-6 bulan yang berjumlah 33 orang. Penelitian dilakukan pada bulan Februari 2017. Analisis data menggunakan Chi Square dengan $\alpha=0,05$. Hasil penelitian diperoleh bahwa mayoritas responden yang berpendidikan rendah paling banyak tidak memberikan ASI Eksklusif, yaitu sejumlah 11 responden (73,3\%). Berdasarkan uji Chi-Square, ada hubungan antara tingkat pendidikan ibu dengan pemberian ASI Eksklusif pada bayi usia 0-6 bulan ( $p$-value $=0,029)$. Responden yang memiliki pengetahuan kurang baik paling banyak tidak memberikan ASI Eksklusif, yaitu sejumlah 12 responden (92,3\%). Berdasarkan uji Chi-Square, ada hubungan antara tingkat pengetahuan ibu dengan pemberian ASI Eksklusif pada bayi usia 0-6 bulan ( $p$-value = 0,032). Diharapkan tenaga kesehatan terus mengembangkan kegiatan promosi mengenai ASI Eksklusif pada ibu sejak masa kehamilan dan terus memotivasi ibu agar memberikan ASI Eksklusif sampai usia 6 bulan.
\end{abstract}

Kata Kunci : Pendidikan, Pengetahuan, ASI Eksklusif, Bayi

\section{Pendahuluan}

Usia bayi merupakan masa pertumbuhan dan perkembangan yang pesat, sehingga kerap diistilahkan periode masa emas sekaligus periode kritis. Periode emas dapat diwujudkan apabila pada masa ini bayi dan anak memperoleh asupan gizi yang sesuai dengan perkembangan optimal, maksudnya disini untuk pertumbuhan dan perkembangan yang optimal anak membutuhkan kalori. Untuk mencapai tumbuh kembang optimal didalam World Health Organisation (WHO) dan United Nation International Children Emerging Fund (UNICEF) merekomendasikan tiga hal penting yang harus dilakukan yaitu : pertama, memberikan air susu ibu kepada bayi segera setelah lahir, kedua memberikan hanya air susu ibu (ASI) saja atau pemberian ASI secara eksklusif sampai bayi berusia enam bulan, ketiga memberikan makanan pendamping ASI (MP-ASI) sejak bayi berusia 6 bulan sampai 24 bulan atau lebih ${ }^{1}$.

Banyak tindakan yang relatif murah dan mudah diterapkan untuk meningkatkan kesehatan dan kelangsungan hidup bayi baru lahir. Tingkat bayi mendapat ASI eksklusif segera setelah lahir sampai 6 bulan baru mencapai 34,5\%. Bahkan, kesadaran masyarakat untuk memberikan ASI pada bayinya memang sangat rendah. Terbukti cuma sekitar $31 \%$ bayi di Indonesia yang mendapatkan ASI selama 6 bulan. Selain itu, hanya $41 \%$ anak usia 6 sampai 23 bulan yang mendapatkan makanan pendamping ASI (MP-ASI) yang tepat sesuai anjuran $\mathrm{WHO}^{2}$.

UNICEF menyatakan bahwa sebanyak 30.000 kematian bayi di Indonesia dan 10 juta kematian anak balita di dunia pada tiap tahunnya, bisa dicegah melalui pemberian ASI secara eksklusif selama enam bulan sejak awal kelahirannya, tanpa harus memberikan makanan serta minuman tambahan kepada bayi. Endmond juga mendukung pernyataan UNICEF tersebut, bahwa bayi yang diberi susu formula, memiliki kemungkinan atau peluang untuk meninggal dunia pada bulan pertama 
kelahirannya 25 kali lebih tinggi dibandingkan dengan bayi yang disusui oleh ibunya secara eksklusif ${ }^{3}$.

Masih banyak beredar mitor-mitos yang beredar di masyarakat tentang ASI Eksklusif yang disampaikan secara turun temurun, anjuran, larangan dari orang tua yang beredar di masyarakat membuat seorang ibu kurang percaya diri untuk memberikan ASI pada bayinya, ketakutan yang tidak beralasan membuat ibu berhenti menyusui dan beralih pada susu formula. Selain itu mereka mempunyai pandangan bahwa menyusui dapat membuat tubuh menjadi rusak, gemuk, dan payudara kendur. Pengetahuan atau kognitif merupakan dominan yang sangat penting untuk terbentuknya tindakan seseorang (overt behavior). Dari pengalaman dan penelitian ternyata perilaku yang didasari oleh pengetahuan akan lebih langgeng daripada perilaku tanpa didasari oleh pengetahuan ${ }^{4}$.

Perilaku pemberian nutrisi pada bayi usia 0-6 bulan juga sangat dipengaruhi oleh tingkat pengetahuan orang tua, keadaan budaya setempat, karena mitos-mitos dalam masyarakat masih sangat kental dan masyarakat masih sangat mempercayai mitos tersebut. seperti anggapan bahwa tidak boleh langsung menyusui setelah bersalin karena ASI yang keluar pertama kali di anggap sebagai susu basi. Sehingga sebelum bayi berusia 6 bulan bayi sudah di berikan makanan tambahan, padahal perilaku tersebut merupakan perilaku yang salah. Selain itu, banyak sekali alasan orang tua memberikan makanan pendamping ASI (MPASI) sebelum bayi berusia 6 bulan, seperti beranggapan bahwa anaknya kelaparan dan akan tidur nyenyak jika diberi banyak makan. Meskipun tidak ada relevansinya, banyak yang mengira ini benar. Karena belum sempurna, system pencernan bayi harus bekerja lebih keras untuk mengolah dan memecah makanan ${ }^{5}$.

Berdasarkan survey awal, dari 6 ibu yang memiliki bayi di desa Meranti, sebagian besar orang tua bayi hanya berpendidikan dasar (SD, SMP) dan ada beberapa yang bependidikan menengah (SMA). Namun meskipun terdapat orang tua yang berpendidikan tinggi, perilaku pemberian nutrisi pada bayi usia 0-6 bulan masih masih banyak yang kurang tepat. 3 orang tua bayi (50\%) sudah memberikan susu formula sejak usia 2 bulan. Penelitian ini bertujuan untuk melihat hubungan antara pendidikan dan pengetahuan ibu dengan pemberian ASI Eksklusif pada bayi usia 0-6 bulan di Desa Meranti, Kab. Merangin, Jambi tahun 2017.

\section{Metode Penelitian}

Desain penelitian yang digunakan adalah penelitian deskriptif korelasi, yang bertujuan untuk menjelaskan hubungan antara variabel bebas dengan variabel terikat, yaitu hubungan tingkat pendidikan dan pengetahuan ibu dengan pemberian ASI Eksklusif pada bayi usia 0-6 bulan di Desa Meranti, Kab. Merangin, Jambi tahun 2017.

Populasi dalam penelitian ini adalah seluruh ibu yang memiliki bayi usia 0-6 bulan yang berjumlah 33 orang. Sampel berjumlah 33 responden dengan tehnik total populasi. Penelitian dilakukan pada bulan Februari 2017. Pengumpulan data menggunakan data primer, yaitu pengisian kuesioner. Analisis data menggunakan analisis Chi Square dengan $\alpha=0,05$.

\section{Hasil Dan Pembahasan}

a. Tingkat Pendidikan Responden

Tabel 1. Distribusi Frekuensi Berdasarkan pendidikan ibu yang memiliki bayi usia 0-6 bulan di Desa Meranti, Kab. Merangin, Provinsi Jambi

\begin{tabular}{lllr}
\hline No & Pendidikan & \multicolumn{2}{c}{ Distribusi } \\
\cline { 3 - 4 } & F & $\%$ \\
\hline 1. & $\begin{array}{l}\text { Pendidikan } \\
\text { Rendah(SD, }\end{array}$ & 15 & 45.5 \\
2. & $\begin{array}{l}\text { SMP) } \\
\text { Pendidikan } \\
\text { Menengah } \\
\text { (SMA) }\end{array}$ & 13 & 39.3 \\
3. & $\begin{array}{l}\text { Pendidikan } \\
\text { Tinggi }\end{array}$ & 5 & 15.2 \\
\hline & Jumlah & $\mathbf{3 3}$ & $\mathbf{1 0 0}$ \\
\hline
\end{tabular}

Berdasarkan hasil penelitian menunjukkan bahwa terdapat 15 responden $(45,5 \%)$ yang mempunyai tingkat pendidikan dasar (SD, SMP), terdapat 13 responden (39.3\%) mempunyai tingkat pendidikan menengah (SMA) dan terdapat 5 responden (15.2\%) mempunyai tingkat pendidikan tinggi. 
Pendidikan secara umum adalah segala upaya yang direncanakan untuk mempengaruhi orang lain baik individu, kelompok, atau masyarakat sehingga mereka melakukan apa yang diharapkan oleh pelaku pendidikan ${ }^{4}$ Materi pendidikan ialah segala sesuatu oleh pendidik langsung diberikan kepada peserta didik dalam rangka mencapai tujuan pendidikan. Dalam praktek pendidikan baik dilingkungan keluarga di sekolah maupun di masyarakat luas banyak sekali tujuan pendidikan yang dinginkan oleh pendidik agar dapat dicapai (dimiliki) oleh peserta didiknya. Peserta didik dalam usia dan tingkat kelas yang sama bisa memiliki profil materi pengetahuan yang berbeda-beda. Hal ini tergantung kepada konteks yang mendorong perkembangan seseorang ${ }^{6}$.

Dengan adanya pendidikan, maka akan timbul dalam diri seseorang untuk berlomba-lomba dan memotivasi diri untk lebih baik dalam segala aspek kehidupan. Pendidikan merupakan salah satu syarat untuk lebih memajukan pemerintah dimana pendididikan dimulai dari tingkat SD sampai pendidikan di tingkat universitas. Hal ini sesuai dengan tujuan pendidikan nasional dalam UUD 1945 pasal 31 ayat 3 menyebutkan, "Pemerintah mengusahakan dan menyelenggarakan satu sistem pendidikan nasional, yang meningkatkan keimanan dan ketakwaan serta ahklak mulia dalam rangka mencerdaskan kehidupan bangsa, yang diatur dengan undang-undang”.

Selain itu juga diatur dalam UU No 20 tahun 2003, menyebutkan bahwa, "Pendidikan nasonal berfungsi mengembangkan kemampuan dan membentuk watak serta peradaban bangsa yang bermartabat dalam rangka mencerdaskan kehidupan bangsa, bertujuan untuk berkembangnya potensi peserta didik agar menjadi manusia yang beriman dan bertakwa kepada Tuhan Yang Maha Esa, berahklak mula, sehat, berilmu, cakap, kreatif, mandiri, dan menjadi warga Negara yang demokratis serta bertanggung jawab"7.

b. Tingkat Pengetahauan Responden

Tabel 2. Distribusi Frekuensi Berdasarkan Pengetahuan ibu tentang pemberian ASI Eksklusif pada bayi usia 0-6 bulan di Desa Meranti, Kab. Merangin, Jambi

\begin{tabular}{llcc}
\hline \multirow{2}{*}{ No } & Pengetahuan & \multicolumn{2}{c}{ Distribusi } \\
\cline { 3 - 4 } & & $\mathrm{F}$ & $\%$ \\
\hline 1 & Baik & 8 & 24.2 \\
2 & Cukup & 12 & 36.4 \\
3 & Kurang & 13 & 39.4 \\
\hline & Jumlah & $\mathbf{3 3}$ & $\mathbf{1 0 0}$ \\
\hline
\end{tabular}

Berdasarkan hasil penelitian menunjukkan bahwa terdapat 13 responden $(39,4 \%)$ ibu yang mempunyai tingkat pengetahuan kurang, terdapat 12 responden $(36,4 \%)$ ibu yang mempunyai tingkat pengetahuan cukup dan terdapat 8 responden $(24,2 \%)$ ibu mempunyai tingkat pengetahuan baik.

Pengetahuan adalah hasil tahun dari manusia yang sekedar menjawab pertanyaan "what" yang terjadi setelah orang melakukan penginderaan terhadap suatu obyek tertentu. Pengetahuan tidak lepas dari pendidikan yang diterima oleh ibu. Umumnya semakin tinggi pendidikan formal yang dicapai oleh ibu, maka semakin baik pula proses pemahaman ibu dalam menerima sebuah informasi. Pengetahuan ini dapat diperoleh dari pengamatan secara informasi yang di dapat seseorang. Pengetahuan dapat didasari oleh pengalaman, social budaya, keyakinan dan usia yang mempengaruhi perkembangan intelektual serta aspek fisiologis yang mana menentukan dalam mendapatkan pengetahuan ${ }^{4}$.

Dari hasil penelitian, paling banyak responden memiliki pengetahuan kurang baik, yaitu 13 responden $(39,4 \%)$. Hal ini dilihat dari jawaban responden yang tidak tahu tentang pengertian ASI Ekslklusif, kandungan ASI, zat kekebalan pada ASI, manfaat ASI Eksklusif dan cara menyusui dengan baik dan benar. Masih banyak keluarga yang mempercayai bahwa jika hanya memberikan ASI saja bayi capat lapar dan rewel, faktor ini yang sangat banyak masyarakat belum mengerti dan mengetahui kapan seharusnya makanan tambahan tersebut diberikan. Padahal jika sebelum bayi berusia 6 bulan sudah di berikan makanan selain ASI akan dapat menyebabkan sembelit ataupun diare. Anggapan bahwa ASI yang pertama keluar harus di buang karena merupakan susu basi, padahal ASI yang pertama keluar tersebut merupakan kolostrum yang kandungan protein dan zat 
kekebalannya sangat tinggi dan sangat dibutuhkan oleh bayi. Anggapan ini sangat dipercayai oleh masyarakat ditengah usaha pemerintah yang sedang menggombar-gemborkan tentang ASI eksklusif memang sangat memprihatinkan, namun fenomena ini dapat terjadi mungkin disebabkan karena masyarakat yang acuh tak acuh dengan pemberitaan tersebut, atau mungkin bahkan bidan desa yang kurang aktif dalam memberikan penyuluhanpenyuluhan pada saat posyandu ${ }^{8}$.

c. Perilaku pemberian ASI Eksklusif pada bayi usia 0-6 bulan

Tabel 3. Distribusi Frekuensi Berdasarkan Pemberian ASI Eksklusif pada bayi usia 0-6 bulan di Desa Meranti, Kab. Merangin, Jambi

\begin{tabular}{llcc}
\hline No & ASI & \multicolumn{2}{c}{ Distribusi } \\
\cline { 3 - 4 } & Eksklusif & F & $\%$ \\
\hline 1 & Ya & 10 & 30.3 \\
2 & Tidak & 23 & 69.7 \\
\hline & Jumlah & $\mathbf{3 3}$ & $\mathbf{1 0 0}$ \\
\hline
\end{tabular}

Berdasarkan hasil penelitian menunjukkan bahwa ibu yang memiliki bayi usia $0-6$ bulan sebanyak 23 responden $(69,7 \%)$ tidak diberikan ASI Eksklusif dan sebanyak 10 responden (30,3\%) diberikan ASI Eksklusif.

Sebagian besar perilaku respoden tidak baik dalam pemberian ASI Eksklusif pada bayi $0-6$ bulan, yaitu sebanyak 23 responden $(69,7 \%)$. Dari hasil penelitian diperoleh bahwa kegagalan ASI Eksklusif dipengaruhi oleh kurang pemahaman orang tua, yang seharusnya diberikan ASI saja secara tanpa makanan tambahan lainnya. Sebagian bayi sudah diberikan makanan bubur sejak usia 4 bulan, diberi susu formula sejak lahir. Hal ini sesuai dengan pendapat Widuri (2013) bahwa ASI Eksklusif adalah pemberian ASI dari ibu terhadap bayinya yang diberikan tanpa makanan atau minuman lainnya termasuk air putih atau vitamin ambahan lainnya tetapi dalam hal ini tidak diterapkan oleh ibu di desa Meranti, Kabupaten Merangin Jambi tersebut ${ }^{9}$.

Berdasarakan hasil penelitian, alasan responden sudah memberi susu formula sejak bayi lahir berpendapat bahwa jika diberikan ASI saja maka bayinya gampang rewel dan takut tidak kenyang. Menurut Sulistyawati (2009) penyebab bayi rewel dan menangis adalah bukan hanya lapar saja, tetapi dapat dikarenakan bayi mengompol, sakit, posisi menyusi yang kurang tepat, atau karena bayi sedang mencari perhatian ${ }^{10}$.

Selain itu juga disebabkan karena ASI yang keluar hanya sedikit, padahal sedikitnya ASI yang keluar sedikit tersebut di sebabkan karena ibu jarang menyusui bayinya secara terus menerus sehingga produksi ASI berkurang, cara memperbanyak produksi ASI adalah dengan menyusui tanpa terjadwal dan terus menerus ${ }^{11}$.

d. Hubungan antara Tingkat Pendidikan Ibu dengan Pemberian ASI Eksklusif pada Bayi usia 0-6

Tabel 4. Distribusi frekuensi Tingkat Pendidikan Ibu dengan Pemberian ASI Eksklusif pada Bayi usia 0-6 di Desa Meranti, Kab. Merangin

\begin{tabular}{|c|c|c|c|c|c|c|c|c|}
\hline \multirow{3}{*}{$\begin{array}{l}\text { Tingkat } \\
\text { Pendidika } \\
\text { n }\end{array}$} & \multicolumn{4}{|c|}{$\begin{array}{c}\text { Pemberian ASI } \\
\text { Eksklusif }\end{array}$} & \multicolumn{2}{|c|}{ Total } & \multirow[t]{2}{*}{$\mathbf{X}^{2}$} & \multirow[t]{2}{*}{$\rho$} \\
\hline & \multicolumn{2}{|c|}{ Ya } & \multicolumn{2}{|c|}{ Tidak } & \multirow[b]{2}{*}{$\mathbf{F}$} & \multirow[b]{2}{*}{$\%$} & & \\
\hline & $\mathbf{F}$ & $\%$ & $\mathbf{F}$ & $\%$ & & & & \\
\hline \multirow{7}{*}{$\begin{array}{l}\text { Pendidikan } \\
\text { rendah } \\
\text { Pendidikan } \\
\text { menengah } \\
\text { PT }\end{array}$} & 4 & 26 & 11 & 73.3 & 1 & 100 & 70 & 0.02 \\
\hline & & .7 & & & 5 & & 89 & 9 \\
\hline & 2 & & 11 & 84.6 & & 100 & & \\
\hline & & 15 & & & 1 & & & \\
\hline & 4 & .4 & 1 & 20.0 & 3 & 100 & & \\
\hline & & 80 & & & 5 & & & \\
\hline & & .0 & & & & & & \\
\hline \multirow[t]{2}{*}{ Jumlah } & 10 & 30 & 23 & 69,7 & 3 & 100 & & \\
\hline & & ,0 & & & 3 & & & \\
\hline
\end{tabular}

Tabel 4 menunjukkan bahwa responden yang berpendidikan rendah paling banyak adalah responden tidak memberikan ASI Eksklusif, yaitu sebanyak 11 responden $(73,3 \%)$ dan yang memberikan ASI Eksklusif sejumlah 4 responden $(26,7 \%)$, responden yang berpendidikan menengah paling banyak adalah responden tidak memberikan ASI Eklsusif, yaitu sejumlah 11 responden $(84,6 \%)$ dan yang memberikan ASI Eksklusif sejumlah 2 responden $(15,4 \%)$ dan responden yang berpendidikan tinggi paling banyak memberikan ASI Eksklusif, yaitu sejumlah 4 responden $(80 \%)$ dan yang tidak memberikan ASI Eksklusif sejumlah 1 responden (20\%).

Tehnik analisis yang digunakan untuk mengetahui hubungan antara tingkat pendidikan dengan pemberian ASI 
Eksklusif pada bayi usia 0-6 di desa Meranti, Kab. Merangin dengan tingkat kesalahan $\alpha=0,05$. Dengan perhitungan uji statistik diperoleh nilai $p$ value $=$ 0,029 . Karena nilai $\mathrm{p}<0.05$ sehingga dapat disimpulkan bahwa Ho ditolak yang berarti terdapat hubungan antara tingkat pendidikan dengan pemberian ASI Eksklusif pada bayi usia 0-6 bulan di desa Meranti, Kab. Merangin.

Sebagian besar responden yang tingkat pendidikan rendah dan menengah memiliki perilaku yang tidak baik, artinya hampir 50\% responden tidak memberikan ASI nya secara eksklusif. Perilaku manusia merupakan hasil pengalaman serta interaksi manusia yang terwujud dalam bentuk pengetahuan sikap dan tindakan. Dengan tingkat pendidikan yang tinggi dapat mempengaruhi perilaku seseorang dalam pemberian gizi yang bermutu baik. Begitu juga dengan pendidikan yang rendah juga akan berpengaruh terhadap perilaku ibu dalam pemberian ASI secara Eksklusif.

Pendidikan dapat meningkatkan kemampuan seseorang pada ranah kognitif, yaitu pengetahuan. Ranah afektif, yaitu penentuan sikap. Dan ranah psiomotorik, yaitu kemampuan mempersepsikan. Tingkat pendidikan berhubungan dengan kemampuan menerima informasi kesehatan dari media massa dan petugas kesehatan. Termasuk dalam informasi tentang ASI Ekslusif. Tenaga kesehatan sudah sering memberikan informasi tentang ASI dalam bentuk penyuluhan, poster di puskesmas tetapi masih banyak yang kurang memahami manfaat dan kegunaan ASI untuk bayi. Banyak kasus kesakitan dan kematian masyarakat diakibatkan rendahnya tingkat pendidikan penduduk ${ }^{12}$.

e. Hubungan antara Tingkat Pengetahuan Ibu dengan Pemberian ASI Eksklsuif pada Bayi usia 0-6 di Desa Meranti, Kab. Merangin

Tabel 5. Distribusi frekuensi Tingkat Pengetahuan Ibu dengan Pemberian ASI Eksklsuif pada Bayi usia 0-6 di Desa Meranti, Kab. Merangin

\begin{tabular}{llllllll}
\hline \multirow{2}{*}{$\begin{array}{l}\text { Tingkat } \\
\text { Pengetah } \\
\text { un }\end{array}$} & \multicolumn{3}{c}{$\begin{array}{c}\text { Pemberian ASI } \\
\text { Eksklusif }\end{array}$} & \multirow{2}{*}{ Total } & $\mathbf{X}^{2}$ & $\rho$ \\
\cline { 2 - 5 } & Ya & \multicolumn{3}{c}{ Tidak } & & & \\
\cline { 2 - 6 } & F & $\%$ & F & $\%$ & F & $\%$ & \\
\hline
\end{tabular}

\begin{tabular}{lllllllll}
\hline Kurang & 1 & 7.7 & 12 & 92.3 & 13 & 100 & 69 & 0.0 \\
Cukup & 4 & 33.3 & 8 & 66.7 & 12 & 100 & 10 & 32 \\
Baik & 5 & 62.5 & 3 & 37.5 & 8 & 100 & & \\
\hline Jumlah & $\mathbf{1 0}$ & $\mathbf{3 0 , 0}$ & $\mathbf{2 3}$ & $\mathbf{6 9 , 7}$ & $\mathbf{3 3}$ & $\mathbf{1 0 0}$ & & \\
\hline
\end{tabular}

Tabel 5 menunjukkan bahwa responden yang memiliki pengetahuan kurang tidak memberikan ASI eksklusif, yaitu sejumlah 12 responden $(92,3 \%)$ dan yang memberikan ASI Eksklusif sejumlah 1 responden (7,7\%), responden yang pengetahuan cukup paling banyak adalah responden tidak memberikan ASI eksklusif yaitu sejumlah 8 responden $(66,7 \%)$ dan yang memberikan ASI eksklusif sejumlah 4 responden $(33,3 \%)$ dan responden yang pengetahuan baik paling banyak adalah responden yang memberikan ASI eksklusif yaitu sejumlah 5 responden $(62,5 \%)$ dan yang tidak memberikan ASI eksklusif sejumlah 3 responden $(37,5 \%)$.

Tehnik analisis yang digunakan untuk mengetahui hubungan antara tingkat pengetahuan dengan pemberian ASI eksklusif pada bayi usia 0-6 di desa Meranti, Kab. Merangin dengan tingkat kesalahan $\alpha=0,05$. Dengan perhitungan uji statistik didapatkan nilai $p$ value $=$ 0,032 . Karena nilai $p$ value $<0.05$ sehingga dapat disimpulkan bahwa Ho ditolak yang berarti terdapat hubungan antara tingkat pengetahuan dengan pemberian ASI eksklusif pada bayi usia 06 bulan di desa Meranti, Kab. Merangin.

Ibu-ibu yang memiliki pengetahuan rendah, wawasan pengetahuan terbatas dan tradisi turun temurun merupakan factor yang mendukung timbulnya anggapan bahwa ASI saja tidak cukup untuk makanan bayi. Akibatnya, para ibu memberikan bentuk cairan sebagai makanan pendamping ASI sebelum biasanya memberikan makanan tambahan pada bayinya sebelum bayinya mencapai rusia 4 bulan dan biasanya lagi diikuti oleh kesalahan dalam memilih jenis dan cara mengolah makanan tersebut ${ }^{8}$.

Masih ada beberapa responden yang tidak tahu manfaat dari ASI, seperti ASI mngandung banyak protein, memberikan anti body pada bayi sehingga bayi tidak mudah terserang penyakit. Hal ini sesuai dengan teori dari Kristiyansari (2009), bahwa ASI mengandung komposisi yang tepat, mengandung antibody, bayi terhindar dari alergi, 
membantu pertumbuhan otak yang optimal, meningkatkan kecerdasan bayi dan ASI adalah nutrisi terbaik bagi bayi ${ }^{13}$.

Namun dapat dilihat juga bahwa masih terdapat responden yang memiliki tingkat pengetahuan tinggi tetapi perilaku pemberian nutrisi terhadap bayinya masih tidak baik dengan tidak memberikan ASI Ekslklusif, hal ini mungkin bisa disebabkan karena ibu malas untuk menyusui bayinya, pengaruh body image bahwa dengan menyusui bayinya maka bentuk tubuh ibu akan menjadi jelek atau terlihat gemuk sehingga ibu menjadi tidak percaya diri, selain itu juga bisa disebabkan karena kecemasan ibu jika hanya diberikan ASI saja bayi tidak kenyang dan rewel sehingga ibu memberikan seperti bubur saring, pisang maupun susu furmula. Selain itu ibu-ibu masih terpengaruh dengan promosipromosi di media sehngga tetap memberikan susu formula meskipun usia bayi dibawah 6 bulan.

Meskipun kesadaran dan pengetahuan ibu tentang gizi sudah tinggi tetapi apabila tidak didukung oleh fasilitas seperti pelayanan kesehatan maka mereka (ibu-ibu) sulit untuk mewujudkan perilaku tersebut khususnya pemberian MP-ASI. Disini peran bidan untuk lebih untuk lebih gencar lagi memberikan penyuluhanpenyuluhan tentang ASI eksklusif dan kader untuk memotivasi masyarakat supaya dapat meningkatkan dan memperbaiki perialku-perilaku yang salah dalam pemberian nutrisi terhadap bayinya ${ }^{4}$.

\section{Kesimpulan}

Berdasarkan penelitan diperoleh hasil bahwa ada hubungan tingkat pendidikan ibu dengan pemberian ASI Eksklusif pada bayi usia 0-6 bulan ( $p$ value $=0,029$ ). Ada hubungan antara tingkat pengetahuan ibu dengan pemberian ASI Eksklusif pada bayi usia $0-6$ bulan $(p$-value $=0,032)$.

\section{Daftar Pustaka}

[1] Suryoprajogo. Keajaiban Menyusui. Yogyakarta: Keyword; 2009.

[2] Fika, Syafiq. IInisiasi Menyusu Dini dan ASI Eksklusif. Jakarta: Kedokteran Trisakti; 2003.

[3] Edmond IO ZC, Quigley MA, Amenga_etego S, S Owusu-Agyei $\mathrm{S}$ and Kirkwoo BR. Delayed Breastfeeding Initiation Increases Risk of Neonatal Mortality. Pediatrics. 2009.

[4] Notoatmodjo, Soekidjo. Perilaku Kesehatan. Jakarta: Rineka Cipta; 2010.

[5] Adiningrum, Hapsari. Buku Pintar ASI Eksklusif. Jakarta Timur: Salsabila Pustaka Alkautsar Group 2014.

[6] Fuad, Ihsan. Dasar-dasar Kependidikan. Jakarta: Rineka Cipta; 2008.

[7] Undang-Undang No 20 Tahun 2003. Sistem Pendidikan Nasional. Jakarta.

[8] Roesli, Utami. Mengenal ASI Eksklusif. Jakarta: Trubus Agriwidya; 2007.

[9] Widuri, Hesti. Cara Mengenal ASI Ekslklusif. Yogyakarta: Gosyen Publishing; 2013.

[10] Sulistyawati, Ari. Buku Ajar Asuhan Kebidanan pada Ibu Nifas. Yogyakarta: ANDI OFFSET; 2009.

[11] Maryunani, Anik. Asuhan pada Ibu dalam Masa Nifas (Pos Partum). Jakarta: TIM; 2009.

[12] Mudjiono. Dimyanti. Belajar dan Pembelajaran. Jakarta: Rineka Cipta; 2009.

[13] Kristiyansari W. ASI : Menyusui dan SADARI. Yogyakarta: Nuha Medika; 2009. 